\author{
BUKE FRANCIS FANG \\ East China Normal University \\ Shanghai (China)
}

\title{
CATHOLIC SEMINARY EDUCATION IN CHINA
}

Abstract: This paper will give an introduction to Catholic seminary education in China. After briefly narrating the political and social changes in modern Chinese history, seminary education will be discussed. Our discussion will focus on restoration, development and decline of Catholic seminaries in China from1982 to the present. Shanghai Sheshan Seminary will be particularly introduced as an example.

Key words: seminary education, Catholic Church, China, formation.

\section{Historical Background}

Today's Catholic Church in China dates back to the Jesuit missionaries who first came to China in the $16^{\text {th }}$ century. The great Jesuit pioneer, Matteo Ricci (1552-1610), took 20 years to work his way step by step to sow the seeds of the Catholic faith in China. It was not until 1692 that the first edict of Catholic toleration was issued by the emperor. However, this limited protection disappeared soon as a result of the Chinese reaction to the Rites Decision from Rome, which declared that Catholics could not participate in Confucian rituals. The emperor got very angry with this and proscribed Christianity in 1721. After that, local Chinese churches went underground to survive. ${ }^{1}$ This event is the so-called Chinese Rites Controversy. ${ }^{2}$

After the 'Opium Wars', ${ }^{3}$ China was forced to sign a series of unequal treaties with Western countries. As a result, China had to open its gate for Westerners to trade, build churches, run schools, etc.

\footnotetext{
${ }^{1}$ Eric O. Hanson, Catholic Politics in China and Korea, Orbis Books, New York 1980.

2 The Chinese Rites controversy was a dispute among Roman Catholic missionaries over the religiosity of Confucianism and Chinese rituals during the $17^{\text {th }}$ and $18^{\text {th }}$ centuries. They debated whether Chinese ritual practices of honoring family ancestors and other formal Confucian and Chinese imperial rites qualified as religious rites and thus incompatible with Catholic faith. Pope Clement XI banned the rites in 1704. In 1721, the Chinese Emperor, Kangxi, disagreed with Clement's decree and banned Christian missions in China.

3 The Opium Wars are two wars between China and Western countries which took place in the periods of 1839-1842 and 1856-1860. The first war was between Great Britain and China. Early in the $19^{\text {th }}$ century, Britain merchants began smuggling opium into China in order to balance their purchases of tea
} 
Most Chinese, including Catholics, recognized that it was a great humiliation for China to reluctantly accept unequal treaties under threat of western military powers. The Catholic Church in China, however, got a historical advantage. As a result, the 120 -year prohibition of the Church mission, which was caused by the Chinese Rites Controversy ended.

Due to this historical background, Christianity in China has been seen as a religion much coloured by colonialism and imperialism. Added to the effect of the 120-year prohibition, Chinese people got a deep negative impression of Christianity.

With some sentiments of narrow nationalism, a rising tide against foreigners swept across the whole of China in the late $19^{\text {th }}$ century. Soon, the 'anti-foreigners' movement became 'anti-foreigner religions'. Missionaries and Chinese Christians also became Chinese people's targets. In the period of the late 19th century and early 20th centuries, Christianity was heavily attacked by rebels. For example, in Beijing City alone, numerous foreign missionaries and Chinese Christians were killed. Twenty churches, 34 foreigners' houses, 24 church schools, 4 convents, and 20 church hospitals were burned by a group of rebels in the so-called 'Boxer Rebellion' ${ }^{4}$

In 1912, the Republic of China was founded. Its constitution clearly announced: 'All citizens have full freedom to practice their religions'. In this new political environment, the Catholic Church rapidly developed and Catholic religious education also appeared, full of vitality. More and more Church schools and seminaries were set up. In 1914, the number of schools run by the Catholic Church reached to 8,034; there were132,850 students in total. Three Catholic universities were also established: in Shanghai (1903), Tianjin (1922) and Beijing (1925). By 1925, there were around 310,000 students in all Catholic schools.

In addition to the schools, the Catholic Church also held 16 regional major seminaries and almost all dioceses had its minor seminary (138 dioceses in China in 1946). By 1949, there were a total of 4,106 seminarians in all the seminaries.

Once the Communist Party took over the regime in 1949, the new government almost immediately initiated the so-called Anti Imperialist Patriotic Movement. In this

for export to Britain. In 1839, China enforced it prohibitions on the importation of opium by destroying at Guangzhou (Canton) a large quantity of opium confiscated from British merchants. Great Britain responded by sending gunboats to attack several Chinese coastal cities. China, unable to withstand modern arms, was defeated and forced to sign the Treaty of Nanjing (1842). This provided that five Chinese ports should be open to British trade and residence; in addition Hong Kong was ceded to the British. In 1856 a second war broke out following an allegedly illegal Chinese search of a British-registered ship. British and French troops took Guangzhou and Tianjin and compelled the Chinese to accept the treaties of Tianjin (1858), to which France, Russia, and the United States were also party. China agreed to open 11 more ports, permit foreign legations in Beijing, sanction Christian missionary activity, and legalize the import of opium.

${ }_{4}^{4}$ The Boxer Rebellion, or the Boxer Uprising was a violent movement by the Righteous Harmony Society in China between 1899 and 1901. It expressed proto-nationalist sentiments and tried to eradicate opposing foreign imperialism and Christian missions. 
movement, foreign missionaries, all of them were seen as imperialists, accomplices or spies, were driven out of China. In 1949-1956, many Chinese bishops, priests, seminarians, sisters, and lay people were put in labour camps or jails. Meanwhile, all church schools, orphanages, and hospitals were taken over by the government to be nationalized or shut.

Between1957 and 1965, many other movements came one after another and religion had to continuously bear their lashes and attacks. Chinese Catholics, despite the grievous suffering endured by many, were fiercely loyal to their Church. Notwithstanding breakdown in relations between the Vatican and China that began in 1957, the great majority continue to be loyal to the Holy See and the universal Church.

In 1966, the unprecedented 'Cultural Revolution' erupted. ${ }^{5}$ It made China sink into great calamity and internal disorder for 10 years until 1976. In these 10 years, any religious activity was strictly prohibited, all the churches were destroyed or occupied for other uses, all the seminaries were closed, and all religious books were burnt. Meanwhile, most clergy, seminarians and nuns were jailed, exiled, or sent to labour camps. Many lay people were also persecuted and humiliated because of their beliefs.

When the churches were allowed to reopen at the end of the 1970s, and the seminaries could restart in the 1980s, there was nothing remained. The Church in China was extremely weak and poor.

By that time, the Catholic Church in China had been isolated from the outside world for almost 30 years. Chinese Catholics even did not know that the Vatican II council had been held in the 1960s.

\section{Restoration}

After the Catholic seminaries were forced to close in the 1950s and the 1960s, there was no seminarian formation in China for two decades. Almost no priests were ordained for close to 30 years, from 1957 to 1985 . By the end of the 1970s - after all the movements and the Cultural Revolution - fewer than 1500 priests remained in all of China. This was one-quarter of the population of priests in 1949 (5788 including both foreign and Chinese priests). The average of a priest was over 70 . There were no priests under 50 years old. This meant that a whole generation of priests was missing in China. Many Chinese nuns were laicized in the 1950s; others were elderly or

${ }^{5}$ The Great Proletarian Cultural Revolution, commonly known as the Cultural Revolution, was a social-political movement that took place in China from 1966 to 1976. Its stated goal was to enforce communism by removing capitalist, traditional and cultural elements from Chinese society, and to impose Maoist orthodoxy within the Chinese Communist Party. Millions of people were persecuted in the violent factional struggles that ensued across the country, and suffered a wide range of abuses including public humiliation, arbitrary imprisonment, torture, sustained harassment, and seizure of property. Historical relics and artifacts were destroyed. Cultural and religious sites were ransacked. After Mao Zedong's death in 1976, reformers led by Deng Xiaoping gained prominence. Very soon the Cultural Revolution was treated officially as a negative phenomenon, and has been ever since. 
infirm. Almost no trained catechists were serving the Church in China at that time. Due to the great shortage of clergy and religious women, reopening seminaries and novitiates to train priests and nuns became the urgent and important mission in the early 1980 s.

In May of 1980, the State Administration for Religious Affairs (SARA) gave the Church permission to reopen seminaries. After bearing heavy pressure for so many years, Catholics' religions emotions were suddenly released and they were full of religious passion and spirit of selfless sacrifices. They devoted themselves to rebuilding the Church in various ways. This heart-stirring atmosphere influenced and attracted young boys and girls to make their decisions to become priests or nuns. For example, each year in the early 1980s more than 100 young boys applied for the entrance exams for Xi' an Seminary (the capital city of Shaanxi Province in central China). We believe that the Holy Spirit had been protecting and guiding the Church in China, so that it still had so much vitality and bred so many precious seedlings of holy vocations.

In order to handle the matter of the Church's extreme urgency and respond to so many young people's thirst for priesthood formation, some dioceses hurried to open informal seminaries at first. The location of the seminary could be temporary and simple. Some were in a corner of a church; some used a private house; some even settled in an abandoned stable. Those who could not find a seminary to get in could live with aging priests as apprentices. The faithful usually treasured those young people who had vocations and provided as much as they could to spiritually and materially support their studies.

In the 1980s, because nothing was left of the Church and many things needed to be done, the few existing priests were extremely busy. Especially before the Church great feast days, only hearing confessions day and night could deplete their energies. With my own eyes, I saw an old lady kneeling at the feet of an elder bishop and speaking with tears: 'Please ordain more priests in a hurry, you and the priests are working too hard!' Even by the most conservative estimates, each priest at that time had to take care of 2000 Catholics.

In October of 1982, Shanghai Sheshan Seminary was opened. It was the first seminary formally established in China after the Cultural Revolution. Thereafter, more and more seminaries sprang up across the country. By the end of the 1980s, there were more than 20 seminaries opened with the authorization of the government. They could be divided into four types of seminaries: national (only 1, in Beijing), regional

${ }^{6}$ Formerly known as Religious Affairs Bureau, it is the government bureau charged with implementing the state's religion policies and enforcing official regulations. It has branches from the national level down to the municipal and district levels. SARA is responsible for registering venues for religious activities and conducting annual inspections of them. It is also charged with authorizing religious professionals. It responsible for monitoring religious activities to ensure their content, locale and leaders are in conformity with official regulations, etc. 
(6), provincial (4), diocesan (more than 10). Besides these, there were a certain number of 'underground' seminaries. ${ }^{7}$

During the 1980s, almost every seminary had more than enough seminarians, but school conditions and management mechanisms were quite poor. First of all, because of the lack proper entrance exams and assessment, many students failed to continue their studies sooner or later. Some did not fit in the community life; some did not have the proper intention for being a priest; some had a level of cultural knowledge that was too low, etc.

In order to improve the quality of education and ensure a better source of students, some major seminaries started preparatory programs or set up minor seminaries. The major seminaries adhered to the principle of enrolling only those who were outstanding in the minor seminaries. The quality of seminary education thus improved, and the success rate considerably increased. According to incomplete statistics, the officially approved seminaries graduated at least 300 priests by 1990. In total, there were over 700 seminarians studying at the seminaries.

Besides these officially approved seminaries, there were also quite a few (the exact number is unknown) underground seminaries. Some of them were opened even earlier than the officially approved ones. Many of them often had to be ready to move from one place to another to avoid the government's prohibition. It was said that the underground seminaries 'graduated' nearly 200 priests by 1990 .

In 1982-1990, all seminaries had the same difficulties and problems, such as shortage of funding, the lack of qualified teachers, a deficiency of books and poor teaching management.

\section{Funding}

School funding of the seminaries mainly depended on each diocese and on donations from abroad. Because the Church in China was restoring itself from the ruins and needed enormous amount of funding, it could not attend to one thing without neglecting the other. So the seminaries often had to bear their financial pressure and limit their development. In addition, with the impact of the social-economical reform and the implementation of the open market economy policy, the price index was rising constantly. Teaching costs rose accordingly. In order to rein in expenditures, some

${ }^{7}$ In the past 60 years, a problem unique to the Catholic Church in China is the break with the Vatican, a situation which divides Chinese Catholics and causes discord in every parish and diocese. Many Catholics, out of loyalty to the Holy See, refuse to attend services at the reopened churches, seminaries or novitiates, all of which are under the supervision of the Chinese Catholic Patriotic Association (CCPA). The result is that there is what many call an 'underground Church' served by so-called loyal priests. In fact, there is only one Catholic Church in China, and this terminology is unfair to those bishops, priests, and religious who serve the Church but remain loyal to the Holy See, pending resolution to this problem. 
seminaries reduced their enrolment, some reduced living standards, some adapted to having larger classes, and so on.

As one family, richer dioceses in coastal areas gave some financial support to the poorer dioceses in the inland and helped them run the seminaries. Meanwhile, the dioceses in the inland that had more vocations generously supported the coastal dioceses with their seminarians. This mutual help to make up what the other lacked also released each seminary's pressure and promoted its development.

In addition, the universal Church paid much attention to the seminaries in China and gave great spiritual and material support. Therefore, each seminary overcame its difficulties and none of them closed due to financial pressures.

\section{Teachers}

In the few years at the beginning, each seminary tried its best to invite priests with noble character and high prestige to teach philosophy and theology and do the administrative work. Among them, there was no lack of erudite priests. However, they had been isolated in jails or labour camps for years and never had a chance to get their knowledge updated.

By the end of the $1980 \mathrm{~s}$, more and more graduated young priests joined the seminary faculty, and aging priests gradually dropped out of teaching and administrating in the seminary because of their ages. In terms of the faculty, almost every seminary finished its succession from old to new.

In the 1980s, although the new ideas and thoughts of Vatican II council had from time to time blown into China like fresh air, the teaching contents in the seminaries were still based on the theories of pre-Vatican II, even the council of Trent. This situation did not essentially change until the end of the 1980s and the early 1990s when foreign professors were allowed to teach at the seminaries.

\section{Textbooks}

In the beginning, the seminaries lacked religious books, as almost all the books were burnt during the Cultural Revolution. They neither had formal textbooks nor reference books. Therefore, some elder priests edited textbooks according to their memories. Later on, more and more Catholics from Hong Kong and Taiwan could come to visit to Mainland China. They took this opportunity to bring some textbooks and reference books to the seminaries. Because the textbooks were few, seminarians often only got the copies which were printed by mimeograph on poor quality paper.

Reference books were very valuable to us at that time. I entered Shanghai Sheshan Seminary in 1989. Although this was the number one in China at that time, and even had recently created its own library through the help of foreign friends, it could not 
ensure that every new seminarian would have a copy of the Bible. I was lucky to have my first Bible in 1990, which was brought to me by a Hong Kong Catholic. I have treasured it ever since.

\section{Administration}

In the 1980s, the administration in Mainland China was a paternalistic kind of management that followed the seminary's traditional management model in a large part. You can imagine the scene of a few priests over the age of 70 teaching and taking care of a group of young seminarians under the age of 30 . Between them, there was a great generation gap. Their speaking, behaviour and way of thinking were very different. In the addition, the younger generation grew up in a social environment lacking a religious atmosphere and did not have good habits for prayer, studies and living. So it was hard to avoid all kinds of contradictions and conflicts. Fortunately, most of the aging priests won people by their virtue. Although the seminarians had some complaints, they never lacked respect for the aging priests.

As some young priests replaced aging priests and gradually assumed the burden of teaching and administration at the seminaries, the situation started to subtly change. Sometimes it seemed that things were getting better but sometimes it seemed that they were getting worse. Young seminarians easily confronted young priests of the seminary faculty if the priests had harsh and stern attitudes to them.

Another thing we have to notice: the faculty priests from both the previous generation and the younger generation were not all 'professional' educators. So it was hard to avoid that their teaching and administration had some unprofessional features. To a certain degree, this also restrained the development of the seminaries.

\section{Growing}

In the 1990s, the seminaries in China showed great improvement. Almost every regional and provincial seminary moved into newly built modern buildings. With help from abroad, administration gradually standardized and the faculty teams grew stronger. Every seminary had enough student resources. In the middle of the 1990s, there were over 1000 seminarians at 12 regional major seminaries.

In terms of the formation model, with help especially from the seminaries in Hong Kong and Taiwan, each seminary started to implement a new model rather than the traditional ways, including new course classification, heuristic education, and raising students' self-awareness about study and prayer. Meanwhile, the seminaries held group Bible study, Taize prayers, and monthly retreats in order to deepen seminarians spiritual experiences. 
During this period, many visiting professors (most were priests and nuns from Hong Kong, Taiwan and other countries) traveled back and forth between abroad and Mainland China. Not only did they teach, but they also paid much attention to instructing and guiding the young faculty teams. These visiting professors made a tremendous contribution to the development of the seminaries.

The 1990s was a historic transition period for Chinese society: the economy was developing rapidly, the culture was getting diversifying, and people's material and spiritual needs were increasing sharply. As a result, the phenomena of 'money worship' and 'hedonism' appeared. In this tide of social-economic development, the Church was also impacted by forces such as secularization. Many Catholics were too busy doing business to go to church.

Some young priests started to pay attention to eating, dressing and enjoying the use of things. Their shortcomings revealed their deficiencies from formation: the superficial roots of their faith, the lack of a sacrificial spirits and their immature personalities. Similar shortcomings appeared in many young seminarians. This became a new and big challenge to seminaries in this period of time.

In order to face these problems and challenges, some seminaries proposed a slogan, which was so-called 'well guard three passes'. The three passes were 'enrolment pass', 'formation pass' and 're-formation pass'. 'Re-formation pass' referred to young priests who had already been doing pastoral work in parishes. They would be invited back to their seminary for a short period of studies and training, usually leading by a group of experienced priests or nuns from abroad. This program was also called 'homecoming activity'. For example, Shanghai Sheshan Seminary held this homecoming activity in 1994, 1996 and 1998. Experience proved that this homecoming activity benefited both the seminary and the homecoming priests. The priests refreshed their minds with updated theological knowledge from their studies and enriched their experiences from pastoral life by sharing them with the other priests. Through this program the seminary found its deficiencies in running the school and also clarified its direction for making efforts.

In terms of the seminaries' construction, development, teaching achievement and the freedom of academic exchange (sending seminarians to study abroad and inviting foreign scholars to come to teach at the seminaries), the 1990s were a 'Golden Age' in Chinese Church history. During this period, the seminaries cultivated many excellent priests who were active in each diocese as pillars. Quite a few of them have become bishops.

\section{Decline}

In the year 2000, there were two events which heavily impacted the Church in China. One was 'January 6th Event'. On 6 January 2000, by virtue of the government's 
manipulation, six priests received episcopal ordination in Beijing without papal approval. Thus, it was not recognized by Vatican. The other event was the so-called Canonization Event. On 1 October 2000, Pope John Paul II canonized 120 Chinese saints at St. Peter's Basilica, and it coincidently took place on China's National Day. The 'January 6th Event' caused the Catholic Church strong dissatisfaction, and the 'Canonization Event' made the Chinese government very angry.

These two events immediately caused in tension in the relationship between Beijing and the Vatican, which had eased up in the 1990s. The contradiction between politics and Catholicism in China, therefore, was once again aggravated.

In this background, the seminaries were tragically influenced: most foreign scholars weren't allowed to teach at the seminaries; many activities, such as academic exchanges, the homecoming activity, overseas study and so on, were restricted or stopped. Many seminaries could not handle the sudden change, especially in dealing with a shortage of teachers.

In the new millennium, the number of seminarians was also remarkably reduced and appeared to have a trend of reducing year by year. In addition to the impact of the social-economic tide, one important reason was the implementation of 'China's One-child Policy', ${ }^{8}$ which started to be applied from 1979. As a result of this policy, from the beginning of this new century, most seminaries in China have been going into decline.

To sum up, all the seminaries in China that were born from the ruins of the Cultural Revolution have made a historical contribution to the Church in China. According to a statistics made by Faith Research Institute, in 2009 there were in total 3397 clergymen (including bishops, priests and deacons) in Mainland China. Over $90 \%$ of them graduated from the seminaries which were opened after the Cultural Revolution. There were 600 seminarians (only half of the number in the middle of the 1990s) studying at major seminaries. In addition, there were around 630 students studying in minor seminaries. ${ }^{9}$

At present, because student resources started to become insufficient, the quality of enrolment is not ensured. Meanwhile, the downsizing in the number of seminarians is making educational costs higher and higher. Therefore, there is a proposal that the

${ }^{8}$ The One-child Policy, officially translated as 'family planning policy', is the population control policy of China. It restricts urban couples to having only one child. This policy was introduced and initially applied from 1979. Chinese authorities claim that the policy has prevented more than 250 million births between 1980 and 2000, and 400 million births from about 1979 to 2011. The policy is controversial both within and outside China because of the manner in which the policy has been implemented and because of concerns about negative social consequences, such as forced abortions, female infanticide, underreporting of female births, sex imbalance, etc. In 2008, China's National Population and Family Planning Commission said that policy will remain in place for at least another decade.

${ }^{9} \mathrm{http}: / /$ www.chinacatholic.org/html/2009/1218/13349.html 
seminaries may someday be open to lay people. It could be another historic transition for the seminaries in China.

\section{Shanghai Sheshan Seminary}

\section{General information}

Shanghai Sheshan Seminary is located in the foothills of Sheshan in the SongJiang District, Shanghai, China. It was founded in 1982 with the intention of forming proper candidates who, hopefully, would later be ordained to support the Catholic community covering six provinces and the Shanghai metropolitan area in their demand of all church activities. The seminary itself was only a small building next to the Sheshan Mid-hill when it was first founded. It was relocated to its current address when the buildings were completed in 1986. The annual open enrolment has consisted of over 730 students in the last 30 years. Nearly 400 of them have been ordained.

\section{Formation goal}

To make it simple, the goal of the seminary is to ready those who are willing to adhere to the life of celibacy and be devoted to evangelization and priesthood by providing them the best and the most appropriate learning environment for philosophical and theological education. Needless to say, they should be inspired by Jesus Christ and follow His will all the time. A simple life style, virginity, and obedience are the very basic rules that they need to follow for their whole life. Those three rules will definitely help them carry out what God would like them to do in this life.

\section{Enrolment}

Applications are received by a branch of the seminary. In June of each year, a special committee screens all the applications and selects the most appropriate ones for the final entrance examination. The examination includes five subjects: Catechism of the Catholic Church, Chinese, English, Chinese and World History, and Political Science. There is also an interview. The committee makes the final decision in terms of admission grants.

\section{Administration}

The formation team at the seminary is in charge of the operations and the management of everything else. Their duties ensure the smooth operations of the seminary in 
addition to students' learning and progress. Their tasks include, but are not limited to, administration, studies, faith formation, liturgy and routine supplies.

Upon the approval of the board directors, the rector leads the formation team and coordinates among all functions. Under him, each office handles different assigned tasks. For example, the dean of studies will set the learning objective, decide on teaching methods, design the curriculum, hire teachers, etc.

\section{Curriculum}

The complete curriculum is designed for a six-year period of study at the seminary: two years for philosophy and four years for theology. At the completion of the philosophical classes, each student is required to submit a paper for the faculty's review. After that, students have one year of practical training in their own dioceses. The trainee is reviewed at the end of the training before the theological classes begin. After four years spent on theology, each student submits a dissertation before the completion certificate is awarded.

The ultimate goal of this 6-year training is to have the best priests ready for all activities related to evangelization, faith formation, strengthening Catholic belief, consecrated life and church governance.

\section{Spiritual training}

Spiritual training is the core of the curriculum. It helps the students build up the relations with the True God and get motivated for the total devotion. All students learn that Catholic worship is ordered by means of liturgy and the celebration of Eucharist as the centre of Catholic belief.

\section{Daily activities}

All students spend each day in the well-designed environment. They go to daily mass, attend all classes, say the rosary prayer and have time for personal prayer/meditation/contemplation, in addition to many other activities. Usually students are not allowed to leave the seminary except on Sundays. Some extra curricular activities are organized to enrich student life at the seminary.

\section{Relations with other communities}

In addition, Sheshan is a famous pilgrimage site in China. This provides a good opportunity for all the students to do a variety of service oriented tasks, especially in the month of May, because May is the month of the Virgin Mary. 
Shanghai is an international city. Sheshan is very close to this big city, so the students are exposed to other communities. Thus, the seminary can receive help and support from surrounding sources and the outside world.

\section{Library}

The library has existed since the seminary building was completed in 1986. A new library building was completed in December 2007. There are two sections: one is foreign language, the other is Chinese. The foreign collection, about 70,000 volumes, includes books mainly in English, French and Latin, plus some in German, Italian, Hebrew and Greek. The subjects cover a wide range of topics from theology to history. Several sets of encyclopaedias are valuable reference tools for everyone at the seminary. Some collections are in the microfiche/microfilm formats. All of the books in foreign languages are classified using the US Library of Congress system. All books in Chinese, about 23,000 volumes, are classified in the Chinese Catalog system.

Most of the foreign collection in the library was donated by various sources in the United States as a result of the help and effort of Father Edward Malatesta, S.J. From 1986 on, he spent humerous hours organizing those books on his trips to China. Bishop Aloysius Jin Luxian, a former rector of the seminary, named the library 'Ai-De' which sounds like Father Malatesta's nickname, 'Ed'. 'Ai-De' in Chinese means 'Love'. This is a true reflection of God's and Fr. Malatesta's love for Shanghai Sheshan Seminary.

\section{Conclusion}

China's Catholic seminary education has experienced an arduous and tortuous journey especially in the past 30 years following the Cultural Revolution. It is symbolic of China's Catholic Church in modern history. There are many experiences and lessons from the history of seminary education in China to summarize and analyse.

In term of 'religious education', China's Catholic seminary education has unique characteristics under its particular social, cultural, economic and political environment. Although facing many problems and difficulties from time to time, the Catholic Church in China has never ceased trying its best to improve seminary education and train more outstanding clergy for the Church.

Meanwhile, we have deeply recognized that the Catholic Church in China is part of the Universal Church. The seminaries in China could not have their achievements and developments without help and support from the whole Church. We also believe that God loves Chinese Catholics so much that He will never allow His sheep to be without good shepherds. 


\section{KATOLICKIE SEMINARIA DUCHOWNE W CHINACH}

Streszczenie: Artykuł stanowi wprowadzenie do tematyki seminariów duchownych w Chinach. W pierwszej części zaprezentowano polityczne i społeczne zmiany ze współczesnej historii Chin, by potem móc przejść do głównego tematu. Przedmiotem analizy jest odnowienie, rozwój i zanik katolickich seminariów w Chinach od 1982 roku po dzień dzisiejszy. Szanghajskie Seminarium Sheshan służy jako przykład.

Słowa kluczowe: seminaria duchowne, Kościół katolicki, Chiny, formacja.

Buke Francis Fang - ksiądz katolicki z diecezji Szanghaj (Chiny), doktorant na East China Normal University w Szanghaju. Zainteresowania badawcze: pedagogika porównawcza.

Adres email: bkfang@yahoo.com 